\title{
Sequence and organization of the lactococcal prolate-headed bIL67 phage genome
}

\author{
Catherine Schouler, S. Dusko Ehrlich and Marie-Christine Chopin
}

\author{
Author for correspondence: Catherine Schouler. Tel: +331346525 22. Fax: +331346525 21. e-mail: \\ schouler@biotec.jouy.inra.fr
}

Laboratoire de Génétique Microbienne, INRA,

Domaine de Vilvert, 78352

Jouy-en-Josas cedex, France

\begin{abstract}
bIL67 is a broad-host-range prolate-headed phage that is active against Lactococcus cells. The complete phage genome sequence of 22195 bp was established. Thirty-seven open reading frames (ORFs) organized in two clusters were identified. Functions were assigned to the putative products of six of the ORFs on the basis of comparison of the deduced amino acid sequences to known proteins, analysis of structural features of the proteins and search for conserved motifs. These were a DNA polymerase, a protein involved in recombination, a lysin, a terminase subunit, a structural protein and a holin.
\end{abstract}

Keywords: bacteriophage, DNA sequence, lactic acid bacteria

\section{INTRODUCTION}

Lactococcal bacteriophages remain a major problem in the dairy industry, since they delay or completely prevent acidification by the starter culture. Many virulent lactococcal bacteriophages have been isolated from unsuccessful fermentations and are classified into 12 species according to morphology and DNA homology (Jarvis $e t$ al., 1991). They have a double-stranded DNA genome ranging from 18 to $54 \mathrm{~kb}$ and carry either cohesive or redundant ends.

Information about genome organization is scarce and concerns only the most prevailing species of lactococcal phages. These species are usually designated according to their morphology and life cycle, and referred to as prolateheaded phages, which are always virulent, and smallisometric-headed phages, which are either virulent or temperate. The genome of virulent small-isometricheaded phages has most probably a modular organization. Such an organization, originally described for lambdoid phages (Campbell \& Botstein, 1983), was suggested by Loof \& Teuber (1986) and Jarvis \& Meyer (1986) from heteroduplex studies that revealed homologous regions covering from 81 to $94 \%$ of the genome and distinct regions of non-homology. Certain regions of smallisometric-headed virulent bacteriophage genomes have been characterized, such as the lysin gene (Platteeuw \& de Vos, 1992), the mcp gene for the major coat protein (Chung et al., 1991), three genes encoding minor structural proteins (Kim \& Batt, 1991), the llaIM gene encoding a

The GenBank accession number for the nucleotide sequence data reported in this paper is L33769.
type-II methyltransferase (Hill et al., 1991), the bpi gene encoding a putative regulator (Lakshmidevi et al., 1990), the per locus presumed to be an origin of replication (Hill et al., 1990), the region surrounding the cos site (Chandry et al., 1994; E. Bidnenko, S. D. Ehrlich \& M.-C. Chopin, unpublished) and a cluster of genes encoding structural proteins (R. Parreira \& others, unpublished). Certain genes from temperate small-isometric-headed phages have also been identified: the int gene encoding the integrase (Lillehaug \& Birkeland, 1993), the repressor (van de Guchte et al., 1994), the lysin gene and genes encoding structural proteins (Arendt et al., 1994). In the case of virulent prolate-headed phages less information is available, since only the lysin genes from three related phages (Shearman et al., 1989; Ward et al., 1993; Geis, 1992) and the N-terminal part of certain structural proteins (Schouler et al., 1992) have been characterized.

A better understanding of the bacteriophage life cycle is required for designing strategies to prevent phage infection. As a step towards this goal, the whole genome (22195 bp) of the prolate-headed phage bIL67 has been sequenced.

\section{METHODS}

Bacterial strains and media. Eschericbia coli JJC128F', araD139 $\Delta($ ara-leu $) 7696$ galE15 galK16 $\Delta(\mathrm{lac}) X 74 \mathrm{hsdr}^{-} \mathrm{bsdm}^{+} \mathrm{Str}^{\mathrm{R}} \mathrm{F}^{\prime}\left[\mathrm{lac} \mathrm{I}^{\mathrm{q}}\right.$ $\Delta$ (lacZ)M15 traD36, was grown at $37^{\circ} \mathrm{C}$ in LB broth (Miller, 1972). Lactococcus lactis IL1403 (Chopin et al., 1984) was grown at $30^{\circ} \mathrm{C}$ in M17 broth (Terzaghi \& Sandine, 1975) in which lactose was replaced by glucose.

Phage bIL67 is from our collection and was propagated on $L$. lactis IL1403. It belongs to the $\mathrm{c} 2$ phage group (Jarvis et al., 
1991). Phage DNA was extracted as described for phage $\lambda$ (Sambrook et al., 1989). Double-stranded DNA of phage M13mp18 (Yanisch-Perron et al., 1985) was purchased from Boehringer.

Molecular cloning and DNA sequencing. E. coli was transformed by electroporation (Dower et al., 1988). Digestion by restriction enzymes, alkaline phosphatase treatment, ligation, luminescent labelling, electrophoresis and hybridization were carried out according to the suppliers' protocols.

The random library of phage genome fragments was established as follows. bIL67 DNA was partially digested with DNaseI (Anderson, 1981). For this purpose, $500 \mathrm{ng}$ of phage DNA, in $100 \mu \mathrm{l} 50 \mathrm{mM}$ Tris $/ \mathrm{HCl}(\mathrm{pH} \mathrm{7.5}) / 1 \mathrm{mM} \mathrm{MnCl}_{2}$, was digested with $2 \times 10^{-3}$ or $2 \times 10^{-4}$ units of enzyme for 5-30 min. The reaction was arrested by addition of EDTA to $50 \mathrm{mM}$ followed by a phenol/ $\mathrm{CHCl}_{3}(1: 1, \mathrm{v} / \mathrm{v})$ extraction. Fragments obtained were made blunt-ended by treatment with $\mathrm{T} 4 \mathrm{DNA}$ polymerase (Boehringer) and were separated in $1.2 \%(\mathrm{w} / \mathrm{v})$ agarose gel. The fragments ranging from 300 to $500 \mathrm{bp}, 500$ to $700 \mathrm{bp}$ and 700 to $900 \mathrm{bp}$ were excised from the gel and recovered by the Freeze-Squeeze procedure using Spin-X tubes as described by the manufacturer (Costar). The isolated fragments were then cloned in M13mp18 which was cut with $S m a I$ and dephosphorylated.

Single-stranded DNA from recombinant phages grown in $E$. coli $\mathrm{JJC} 28 \mathrm{~F}^{\prime}$ was isolated by the perchlorate method (Zimmermann et al., 1989) as adapted for the Beckman BIOMEK 1000 Laboratory Workstation (Sorokin et al., 1993). Singlestranded DNA was sequenced by using Taq polymerase (Applied Biosystems) on CATALYST (Applied Biosystems), or by the Sequenase (Applied Biosystems) procedure, manually. The dye-labelled standard sequencing primers of Applied Biosystems and Applied Biosystems Sequencer ABI-373 were used. Complementary DNA strands of M13 were obtained according to the protocol supplied with Dynbeads (strapavidincoated magnetic beads) template preparation kit (Dynal).

Unclonable regions were synthesized by PCR. Sequencing of PCR products was performed essentially according to the protocol supplied with the Applied Biosystems PCR sequencing kit, on the DNA Thermal Cycler from Perkin-Elmer.

Data handling and computer analysis. DNA sequence assembly was performed using Staden's programmes (Staden, 1982). ORF predictions were performed with Genmark software (Borodovsky \& McIninch, 1993). Sequence data were analysed using the University of Wisconsin Genetics Computer Group (UwGCG) package (Devereux et al., 1984). The search for sequence homology was carried out using FASTA (Pearson \& Lipman, 1988) (in Swissprot release 27) and BLAST (Altschul et al., 1990) (in GenBank release 80). Search for blocks of homology was done using MACAw software (Schuler et al., 1991).

PCR. Reactions were performed using the Gene ATAQ Controller (Pharmacia-LKB) or the DNA Thermal Cycler 9600 (Perkin Elmer). The standard Taq polymerase buffer of Promega, $0.2 \mathrm{mM}$ of each dNTP, $0.1 \mu \mathrm{M}$ primers and 2.5 units Taq polymerase were used. The final volume of the reactions was $100 \mu$ l. Phage bIL67 DNA (50 ng) or phage M13 supernatant $(2 \mu \mathrm{l})$ was used as starting material. The conditions of a cycle were: $94^{\circ} \mathrm{C}$ for $1 \mathrm{~min}, 50^{\circ} \mathrm{C}$ for $2 \mathrm{~min}, 72^{\circ} \mathrm{C}$ for $3 \mathrm{~min}$. In total, 30 cycles of amplification were run. After the PCR reactions were completed, DNA was loaded in $1 \%$ low-gelling agarose gel and purified using the Freeze-Squeeze procedure (Costar).

\section{RESULTS AND DISCUSSION}

\section{Determination of the bIL67 DNA sequence}

The DNA sequencing strategy used follows closely that developed for sequencing of the entire yeast artificial chromosome, within the context of the Bacillus subtilis genome sequencing project (P. Serror, A. Sorokin \& S. D. Ehrlich, unpublished). Briefly, a random library of 960 clones in M13mp18, covering the phage genome 27 times, was established. Seventy-five per cent of the bIL67 sequence was determined by shotgun sequencing of 149 clones. This sequence was organized in 17 non-overlapping clusters of a size ranging from 270 to $2700 \mathrm{bp}$. To fill the gaps between the clusters, PCR-synthesized inserts of M13 phages corresponding to the ends of each cluster were hybridized with the random library. The positive M13 clones were sequenced. Close to $96 \%$ of the sequence was thus determined. This sequence, determined on only one strand in some regions, was completed by synthesis and sequencing of the complementary strand of appropriate clones (see Methods). The remaining $4 \%$ of the genome was apparently absent from the random library, probably because of toxicity and/or of structural instability in the cloning system used. The sequence of this last part was determined directly from PCR products spanning the gaps. Thus, a linear bIL67 DNA sequence of 22195 bp was established, with an average redundancy of $6 \cdot 2$, each region being sequenced at least once on both strands. Restriction sites determined from the sequence analysis were in agreement with those found by endonuclease digestions. The total $\mathrm{G}+\mathrm{C}$ content of the bIL67 phage genome is $36 \%$, which is similar to that of the lactococcal hosts (Kilpper-Bälz et al., 1982).

\section{Genome organization}

The sequence was translated in all six frames and the criterion chosen for ORFs was the presence of a start codon (AUG, UUG or GUG) preceded by a ribosome binding site (RBS) complementary to the $3^{\prime}$ end of the $16 \mathrm{~S}$ rRNA of Lactococcus lactis (3' UCUUUCCUCCA 5') (Ludwig et al., 1985). When no length limitation was set, 37 ORFs could be identified, 11 of which were shorter than $300 \mathrm{bp}$. The protein-coding regions were checked all along the sequence, using a programme developed for gene recognition in newly sequenced DNA (Borodovsky \& McIninch, 1993), which is based on non-homogeneous Markov chains. The presence of the 37 ORFs was thus confirmed. The ORFs were organized in two divergent clusters (Fig. 1). It is tempting to correlate this organization with that deduced from transcriptional studies of the prolate-headed phage $\mathrm{c} 2$ (Beresford $e t$ al., 1993), where early and late regions were identified. As discussed below, putative genes encoding lysin and a structural protein, which were expected to be expressed late, are present in the leftward orientated cluster (Fig. 1). We therefore speculate that this cluster corresponds to the late transcribed region and, accordingly, the other cluster to the early transcribed region (Fig. 1).

Early and late regions are separated by two intergenic regions, the structure of which is detailed below. 


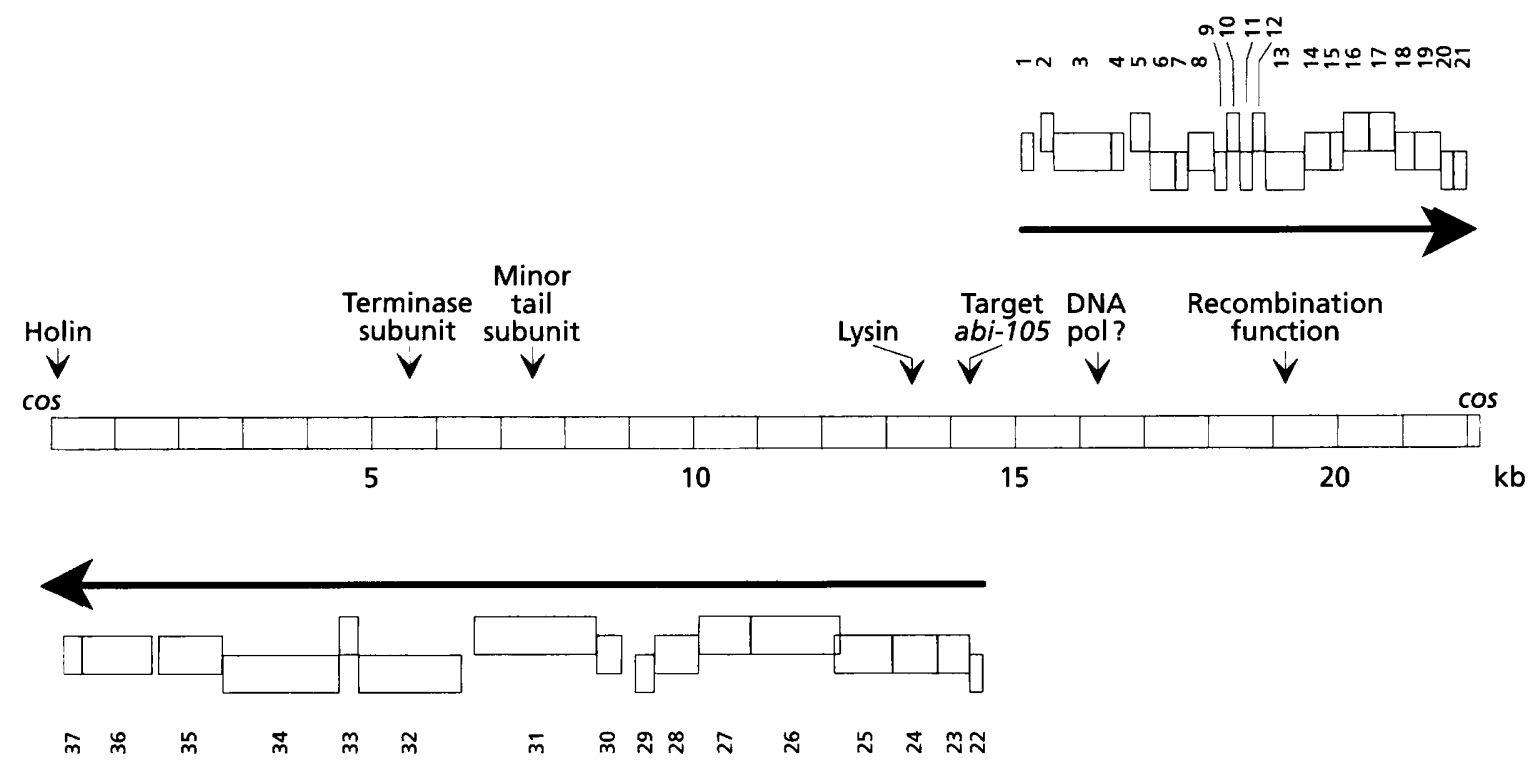

Fig. 1. Genetic organization of the bIL67 genome. The 22195 bp linear genome of bIL67 is represented as an open bar with vertical $1 \mathrm{~kb}$ markers. ORFs are shown in boxes either above or below the genome. They are at three different heights, depending on which of the three frames on each strand is used. Direction of transcription is indicated by arrows. Gene functions are indicated when assigned.

Upstream of the early and the late regions, putative promoters were identified, having an extended -10 consensus box (TATGCTATAAT and TTTTTGATATATT, respectively), and no significant resemblance to the -35 consensus box. Promoters of this type (A/TntnTGa/tTATAAT, lacking a clear -35 sequence) are known to allow $\sigma^{70}$-dependent transcriptional initiation in E. coli (Kumar et al., 1993). One such promoter was recently shown to be functional in another lactococcal phage, bIL66 (E. Bidnenko, S. D. Ehrlich \& M.-C. Chopin, unpublished). Fourteen of the 21 early genes overlap by $1-8$ bp and might, therefore, be transcriptionally coupled. A putative terminator sequence (CCACTCAATCAAGAGTGGTTTTTTGTTT; underlined sequences can form a stem structure) is present $30 \mathrm{bp}$ downstream of the last early gene. A striking feature of the early genes is their small average size, about $350 \mathrm{bp}$. Late genes are, on average, longer and eight of them overlap by 1-50 bp. Translational signals of the 37 identified genes are compiled in Table 1.

\section{Intergenic regions}

The cohesive ends (cos site) of the prolate-headed phage P001 have the sequence 5' TCAAGCCTAACT 3' (Billard et al., 1992). Since the same sequence is present in the intergenic region of bIL.67, in which transcription of early and late genes converge, we propose that it corresponds to the cos site of this phage. This cos site contains a singlestranded 3' overhang, as already observed for several phages active on Gram-positive bacteria. Six different types of direct repeats and one inverted repeat have been identified in the vicinity of the cos site (Fig. 2). The repeats denoted R2 present a dyad symmetry, evocative of those found at the cos site of phage $\lambda$. Some of the structural features near the cohesive ends could be involved in recognition by terminase and host factors.

In the intergenic region upstream of the early and late genes (Fig. 1), which is $680 \mathrm{bp}$ long, several short direct ( $7 \mathrm{bp}$ ) and inverted repeats are present. The role of these repeats is not known, but similar structures are often found in the DNA replication origin. If bi-directional replication were initiated in this region, it would be codirectional with phage transcription. Such codirectionality is observed, for instance, in the chromosome of E. coli and B. subtilis (Burland et al., 1993; Ogasawara et al., 1994; Sorokin et al., 1993).

\section{Putative function of the ORFs}

Using the BLAST (Altschul et al., 1990) and FASTA (Pearson \& Lipman, 1988) programs, similarities between proteins specified by bIL67 ORFs and protein sequences present in databases were searched for. Significant homology was detected for translation products of three ORFs, encoding a recombinase, a lysin and a structural protein. The putative function of three additional proteins can be deduced from the presence of conserved domains and structural features in common with known proteins (a DNA polymerase, a terminase subunit and a holin). In the following sections the relevant ORFs are discussed.

\section{ORFs 3, 4, 5 and 6}

Five domains typical of DNA polymerases have been identified in the protein specified by ORF3 (Fig. 3). Although the overall similarities among distantly related DNA polymerases are weak, three exonuclease domains 
Table 1. General features of the bIL67 ORFs

\begin{tabular}{|c|c|c|c|c|c|c|}
\hline \multicolumn{2}{|c|}{$\begin{array}{c}\text { Gene } \\
\text { designation }\end{array}$} & Start* & Stop* & $\begin{array}{l}\text { Product } \\
\text { size (aa) }\end{array}$ & Similarities & Translation start $\dagger$ \\
\hline Early & 1 & $15132(\mathrm{AUG})$ & 15278 (UGA) & 48 & & AAAGAGGUuuaaau AUG UUU AUU \\
\hline & 2 & 15379 (AUG) & 15579 (UAA) & 66 & & GGAGGUuuuucaa AUG ACA AUA \\
\hline & 3 & $15581(\mathrm{AUG})$ & 16480 (UAA) & 299 & & AAAGGgGUugauuaaa AUG CAG GAC \\
\hline & 4 & $16550(\mathrm{AUG})$ & $16738(\mathrm{UGA})$ & 62 & DNA pol & GAGGUuaccga AUG GAU AAA \\
\hline & 5 & $16735(\mathrm{AUG})$ & 17115 (UAA) & 126 & & AAAGGAacuaaacaa AUG AAA AUU \\
\hline & 6 & $17115(\mathrm{AUG})$ & 17483 (UGA) & 122 & & GAGGUaucaaaua AUG GCG AUU \\
\hline & 7 & $17562(\mathrm{AUG})$ & $17735(\mathrm{UAA})$ & 57 & & GAGGgaacaaaaa AUG AUU AAA \\
\hline & 8 & 17735 (AUG) & $18085(\mathrm{UAA})$ & 116 & & GGAGGUuaaaagaua AUG GCU AAA \\
\hline & 9 & 18138(AUG) & 18263 (UAA) & 41 & & GAGGau AUG GCG AAA \\
\hline & 10 & 18295 (AUG) & 18480 (UAA) & 61 & & AGAAuaucauaaa AUG CUA GGG \\
\hline & 11 & $18480(\mathrm{AUG})$ & $18683(\mathrm{UAA})$ & 67 & & GGAGGUauuaaaua AUG GCA UUA \\
\hline & 12 & $18751(\mathrm{AUG})$ & 18903 (UAA) & 50 & & AAGGAGGaauaaaa AUG UUG ACU \\
\hline & 13 & 18903 (AUG) & 19442 (UAA) & 179 & Erf & AAAGGAGugagccuaua AUG GAA AGC \\
\hline & 14 & $19508(\mathrm{AUG})$ & 19879 (UAA) & 123 & & GAGGgaaacaaaaaa AUG AAA AUU \\
\hline & 15 & $19892(\mathrm{AUG})$ & 20056 (UGA) & 54 & & AAAGGAGuucagga AUG GGAUAU \\
\hline & 16 & $20053(\mathrm{AUG})$ & $20532(\mathrm{UAG})$ & 159 & & GAAAGGaauacauacaaacu AUG AAA AUC \\
\hline & 17 & $20554(\mathrm{AUG})$ & 20887 (UAA) & 107 & & AAAGGggaacgaa AUG UUU AAC \\
\hline & 18 & $20870(\mathrm{AUG})$ & 21 172(UAA) & 100 & & GAGGUaacuacu AUG AUU AAU \\
\hline & 19 & 21 194(AUG) & $21568($ UAA) & 124 & & GAGGaacuaaaaa AUG AAA CUU \\
\hline & 20 & $21573(\mathrm{AUG})$ & 21779 (UAA) & 68 & & GAGGUguaaaaaa AUG GAA UUA \\
\hline & 21 & $21780(\mathrm{AUG})$ & $21953(\mathrm{UAG})$ & 57 & & GAGGUguaa AUG GUU UAU \\
\hline \multirow[t]{16}{*}{ Late } & 22 & $14448(\mathrm{AUG})$ & 14299 (UAA) & 49 & & GGAGGUauaagc AUG GCA GAA \\
\hline & 23 & $14288(\mathrm{AUG})$ & 13803 (UAA) & 161 & $a b i-105$ target & GAGGauagaa AUG AAG AAA \\
\hline & 24 & $13757(\mathrm{AUC})$ & $13077(\mathrm{UAG})$ & 226 & Lysin & GGgGGUgguaau AUC AAA AUA \\
\hline & 25 & $13067(\mathrm{AUG})$ & $12228(\mathrm{UGA})$ & 279 & & AGGAGGaguga AUG AGC UUA \\
\hline & 26 & 12277 (UUG) & 10832 (UAA) & 481 & & AAAGGAGGaaaaa UUG AAA GUA \\
\hline & 27 & 10801 (AUG) & $10097(\mathrm{UAG})$ & 234 & & AGAAAGGgaguaaaua AUG GCU GAA \\
\hline & 28 & 10079 (AUG) & 9462 (UAA) & 205 & & AGGAGGauaaaaauaa AUG GCA UAU \\
\hline & 29 & $9390(\mathrm{AUG})$ & $9136(\mathrm{UAA})$ & 84 & & AGGAGaauagaaaa AUG AAG AAA \\
\hline & 30 & $8948(\mathrm{AUG})$ & $8544(\mathrm{UAA})$ & 134 & & GGAGGUaaaauu AUG GCA AAC \\
\hline & 31 & $8551(\mathrm{AUG})$ & $6689(\mathrm{UGA})$ & 620 & Tail protein & AAGGAGuauaacaaaca AUG GCU AAA \\
\hline & 32 & $6390(\mathrm{AUG})$ & $4834(\mathrm{UAA})$ & 518 & Terminase subunit & AAGGAGauauaaaaaa AUG AGUUUA \\
\hline & 33 & $4834(\mathrm{AUG})$ & $4535(\mathrm{UAA})$ & 99 & & GAGGacuauuuuauuua AUG GCU AUG \\
\hline & 34 & $4542(\mathrm{UUG})$ & $2656(\mathrm{UAA})$ & 628 & & GGAGGgcuuggcga UUG AAU AAG \\
\hline & 35 & $2663(\mathrm{AUG})$ & $1725(\mathrm{UAG})$ & 312 & & AGAAAGGAuau AUG AAU AAA \\
\hline & 36 & $1670(\mathrm{AUG})$ & 477(UAA) & 397 & & GAGGUuugaaaa AUG GAU AGU \\
\hline & 37 & 458(AUG) & 165(UAG) & 97 & Holin & AAAGGAG aagagag AUG AUG AUU \\
\hline
\end{tabular}

$16 \mathrm{~S}$ rRNA 3 UCUUUCCUCCA 5

* Numbers refer to position in the sequene; start and stop codons are shown in parentheses.

$\uparrow$ The RBS and the beginning of the ORFs are shown in capital letters.

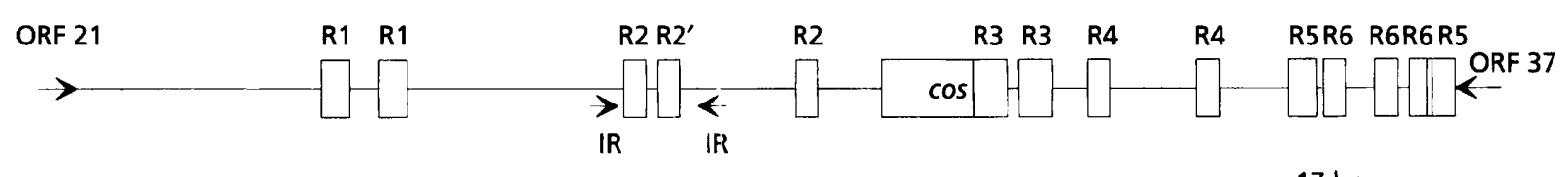

R1: ATACCCCT

R2: CAAAAC

R2': CAAAAT

R3: CACCCCCTITA

R4: AAATTTA

R5: CTATACTAT

R6: TACTATA

cos region: CCTAAAGAGTTAGGCTTGATAGAAAACC

Fig. 2. Region of cohesive ends. The direct repeats are represented by boxes. The inverted repeats are indicated as arrows below the horizontal bar representing the phage DNA. Ends of ORF 21 and ORF 37 are represented as arrows on the horizontal line. Scale, sequence of the repeats and the cos region are shown below the figure. Cohesive ends are boxed. 


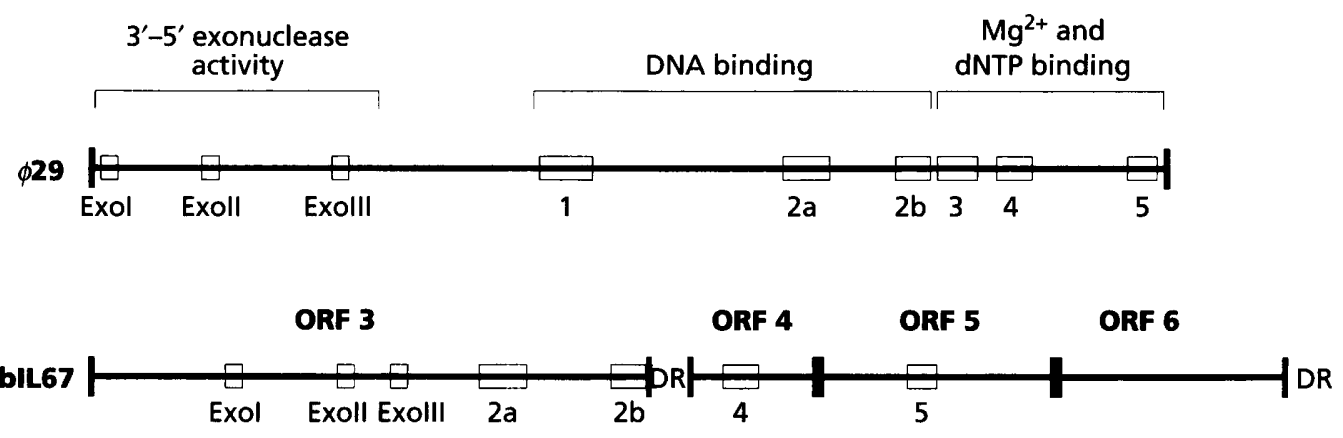

50 aa

Fig. 3. Comparison of the organization of the conserved regions involved in the catalytic activity between $\phi 29$ DNA polymerase and bIL67-encoded products by ORF 3 to ORF 6 . Proteins are represented with the $N$ terminus at the left. Thick vertical lines delimit proteins. Open squares indicate the conserved regions between DNA-dependent DNA polymerases (Blanco et al., 1991). DR refers to direct repeat (see text for sequence).

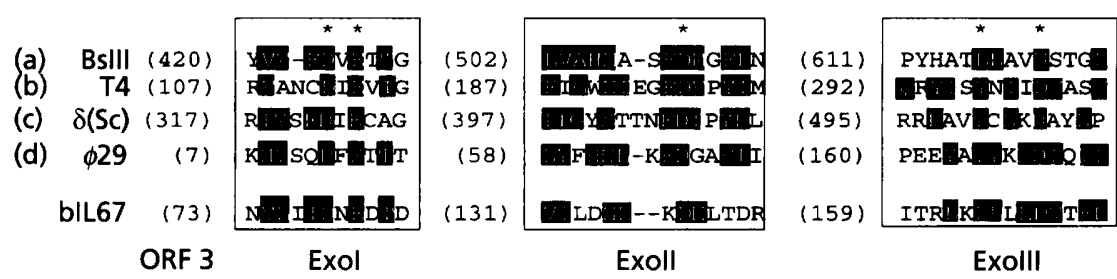

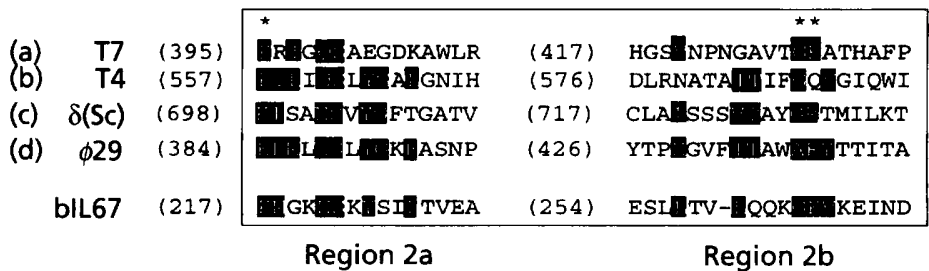

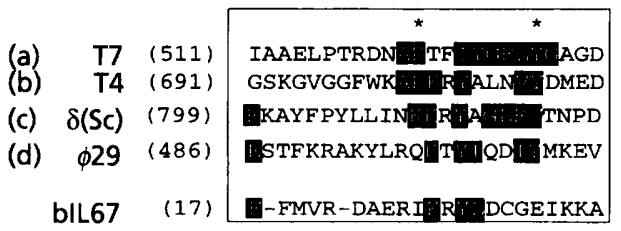

Region 4

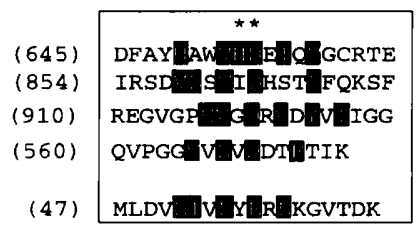

ORF 5

Region 5
Fig. 4. Highly conserved regions within DNA-dependent DNA polymerases and homology with phage blL67. One representative polymerase from each group is presented. (a) Poll-like DNA polymerases represented by BsIII for the exopolymerase domains and by $\mathrm{T} 7$ for the polymerization domains (not characterized for BsIII), (b) viral $\alpha$-like DNA polymerases, (c) cellular $\alpha$-like DNA polymerases, and (d) protein-primed $\alpha$ like DNA polymerases. Numbers in parentheses indicate the amino acid position relative to the $\mathrm{N}$-terminal end of each DNA polymerase. Relevant amino acid similarity among the different groups is indicated in white letters. The following conservative amino acid substitutions were considered: $S$ and $T ; A$ and $G ; K, R$ and $H ; D, E, Q$ and $N ; L, I, M$, $C, V, Y$, and $F$ (Blanco et al., 1991, 1992). Asterisks indicate specially conserved residues and/or Poll residues involved in catalytic activity. located in the $\mathrm{N}$-terminal region and six domains involved in the polymerization function, located in the C-terminal region, have been identified in 27 different enzymes (Blanco et al., 1991). Domains corresponding to $3^{\prime}-5^{\prime}$ exonuclease activity (I, II and III) were found in ORF 3 (Fig. 4). The $\mathrm{Y}$ residue in domain III, which plays an important role in catalytic activity, is replaced by an $\mathrm{L}$ residue in ORF 3, as previously observed for the B. subtilis DNA polymerase BsIII (Blanco et al., 1992). Two domains (region $2 \mathrm{a}$ and region $2 \mathrm{~b}$ ) out of the six involved in the polymerization function were also found in ORF 3 . Remarkably, two additional polymerase domains, known as region 4 and region 5 , are present downstream of ORF
3 in ORF 4 and ORF 5, respectively. Moreover, proteins encoded by ORFs 4 and 5 are basic (pI 10.43 and pI 10.20, respectively) and have one and two helix-turn-helix motifs, respectively, which is indicative of DNA binding capacity. In contrast, polymerase regions 1 and 3 were not identified. It is possible that the proteins encoded by ORFs 4 and 5 are subunits of a DNA polymerase. Interestingly, the cluster composed of ORFs 4, 5 and 6 is flanked by direct repeats of $25 \mathrm{bp}$ (AATTAAGTCATCAAGTTAAGAGAGG), which include a ribosome binding site. This organization is evocative of evolution by exchange of DNA modules, via a Campbell type recombination between two circular molecules, a 
process proposed for lambdoid phages (Campbell ix Botstein, 1983).

\section{ORF 13}

The product of ORF 13 shares $37.5 \%$ identity and $57 \cdot 1 \%$ similarity to the Erf protein of Salmonella typhimurium phage P22 (Poteete, 1982). This protein is required for the circularization of the linear chromosome of the phage, by homologous recombination between its repetitive ends (Weaver \& Levine, 1977). Since bIL67 has cohesive ends;, the ORF 13 product probably plays a different role. In phage $\lambda$, the homologous recombination directed by the red system was shown to increase the amount of packageable DNA (Smith, 1983). The homologous recombination system of phage P22 and phage $\lambda$ are structurally unrelated (Poteete et al., 1991) but functionally interchangeable (Poteete \& Fenton, 1984). We suggest that ORF 13 plays a role similar to $\lambda$ red. Interestingly, ORF 12 , located upstream of ORF 13, encodes a protein of 51 aa. The position of the gene and the size of the protein are evocative of the accessory recombination function (arf) gene of P2? (Poteete et al., 1991). Nevertheless, no significant homology has been observed between ORF 12 and arf gene products. The ORF $12 / 13$ cluster is flanked by two direct repeats of $31 \mathrm{bp}$ with only two mismatche; (in bold letters) (TTGACAAAAGAAAGCAAACACGT TATAATTA and TTGACAAAAGAAAATAAAC. ACGTTATAATTA) which suggests that they may also correspond to an exchangeable module. Interestingly, at promoter consensus sequence (de Vos, 1987) is present in these repeats (underlined). No homologies with other: components of the $\mathrm{P} 22$ or $\lambda$ recombination systems have: been observed in bIL67.

\section{ORF 23}

The ORF 23 product shares over $90 \%$ identity with the protein encoded by the gene located upstream of the lysin gene of the lactococcal prolate-headed phages $\phi \mathrm{VML} 3$ (Shearman et al., 1989) and c2 (Ward et al., 1993), respectively. The function of this gene remains unknown in both cases. Moreover, the ORF 23 product shares $41 \%$ identity with the protein encoded by ORF 3 of the virulent isometric-headed bIL66 phage (E. Bidnenko, S. D. Ehrlich \& M.-C. Chopin, unpublished). ORF 3 of bIL.66 is located in the region which is a target of the abortive infection mechanism abi-105, active against isometric- and prolate-headed phages (including bIL67) (Gautier \& Chopin, 1987). ORF 23 may thus be the target of abi-105. ORF 3, located near the cohesive ends of bIL66, is a middle-expressed gene, while ORF 23, located in the middle of the genome, might be one of the first late genes of bIL67.

\section{ORF 24}

The ORF 24 product shares very high identity (up to $95 \%$ ) with the proteins encoded by the three lysin genes already sequenced from lactococcal prolate-headed phages, $\phi$ VML3 (Shearman et al., 1989), P001 (Geis, 1992) and c2 (Ward et al., 1993). The published $\phi$ VML3 lysin gene sequence (Shearman et al., 1989) has been recently corrected in the database (accession number $\mathrm{X} 16178$ ) and is in good agreement with the one from phage $\mathrm{c} 2$. However, in both cases, the position of the start codon of the gene was unclear. This question was recently answered by the report of the purification of the phage P001 lysin protein and the determination of its $\mathrm{N}$-terminal amino acid sequence, MKVSQ (A. Geis \& S. Hertwig, unpublished). Comparison between this sequence and the one deduced from the nucleotide sequence, revealed that the isoleucine codon, AUC, is used as a start codon (it is translated as the first methionine). Sequence comparisons revealed that the start codon is also AUC in phage bIL67 but AUA in phages $\mathrm{c} 2$ and $\phi \mathrm{VML} 3$. AUA has already been found as a start codon in vivo in E. coli (Belin et al., 1979) but the use of AUC as a start codon has never been reported before. Use of a very rare start codon could be a way to decrease translation of lysin during phage multiplication. The bIL67 lysin gene shares $40.3 \%$ and $49 \cdot 3 \%$ homology with those of $B$. subtilis phages PZA (Paces et al., 1986) and $\phi 29$ (Vlcek \& Paces, 1989), respectively, which were shown to exhibit muramidase activity.

\section{ORF 31}

The ORF 31 product shares $99 \%$ identity with the Nterminal part of protein POA17 from the prolate-headed phage $\phi 197$ (Schouler et al., 1992). However, antibodies raised against POA17 were shown to react with two minor structural proteins of molecular mass 45 and $46 \mathrm{kDa}$, respectively, while ORF 31 encodes a protein of $66 \cdot 2 \mathrm{kDa}$. It is possible that this $66 \cdot 2 \mathrm{kDa}$ protein is processed to fragments of 45 and $46 \mathrm{kDa}$. These proteins were localized at the end of the tail of phage $\phi 197$ by electro-immuno microscopy $(H$. Neve $\&$ P. Ritzenthaler, personal communication). A calcium-binding domain (Nakayama et al., 1992), consisting of a 13 residue loop (DKNHDGKVSQDEM) flanked by $\alpha$-helical domains, named EF-hand, was found from position 413 to 425 . This is most probably related to the calcium requirement for the development of bIL67 and numerous other phages (Potter, 1970). However, it is still unknown if calcium plays a role in the lactococcal phage adsorption via a depolarization of the membrane, as observed for T4 (Letellier \& Labedan, 1985), or participates in DNA injection, as observed for the PL-I Lactobacillus phage (Watanabe \& Takesue, 1972).

\section{ORF 32}

A search for conserved motifs suggests that the ORF 32 gene product could be a DNA binding protein with ATPase activity. Two ATP binding domains and a helix-turn-helix motif were found in the product of ORF 32. The ATP/GTP-binding site motif B (Walker et al., 1982) was found at position 178-190 (TLDGGREQLVIID). The conserved domain which could be involved both in ATP binding and in phosphorylation of the substrate (Brenner, 1987), was found at position 459-482. This domain is observed in a 
Fig. 5. Primary sequence of protein 37 . For comparison, the primary sequence of $\phi 29$ protein 14 is shown above the protein 37 sequence. Identical amino acids are represented by vertical bars and homologous amino acids by colons. The charged side chains are indicated by + or - above the sequence. Potential transmembrane domains, defined as regions of 20 generally hydrophobic residues with no net charge, are underlined. Potential $\beta$-turn regions as predicted by the Chou-Fasman prediction algorithm are indicated by ' $\mathrm{t}$ '. The putative dual start motifs are indicated by arrows.

number of enzymes conferring antibiotic resistance, such as phosphotransferases and protein kinases (Brenner, 1987). The common pair of aspartic residues, presumably involved in the binding through $\mathrm{Mg}^{2+}$ of the phosphate groups of ATP (Brenner, 1987), were found at positions 462 and 479 . Several other residues, less conserved, were also found in this region (data not shown).

Up to now, in all double-stranded DNA bacteriophages studied, the cutting and packaging of the phage chromosome is mediated by the phage-encoded enzyme, terminase. Terminases are ATP-binding and hydrolysing proteins that assemble to form multimeric packaging complexes (Black, 1988). As the product encoded by ORF 32 is the only one among all proteins encoded by the phage having an ATP-binding site, it could be a subunit of the terminase.

\section{ORF 37}

Endolysin activity accumulates in the cytoplasm during the vegetative cycle of many phages (Young, 1992). To gain access to its substrate, the cell wall, the lysin should be released from the cell. The release is thought to require a small (60-130 aa residues) phage-encoded protein, holin, which accumulates throughout the late gene expression period and has been shown, in the case of phage $\lambda$, to make pores in the membrane (Bläsi et al., 1990). Prototype holin genes in phages $\lambda, 21, \mathrm{~T} 7$ and $\phi 29$ share no sequence homology but the distribution of charged and hydrophobic residues is conserved among the different proteins (Young, 1992). The proteins have two membranespanning $\alpha$-helical domains separated by a short loop containing a turn, a short hydrophilic $\mathrm{N}$ terminus and a highly-charged $\mathrm{C}$ terminus. This suggests a common topolngy in the membrane, with both $\mathrm{N}$ - and $\mathrm{C}$-terminal domains located in the cytoplasm (Young, 1992). Usually, the holin proteins exhibit a dual translational start motif (Young, 1992). All these characteristics were found for the protein encoded by ORF 37 (Fig. 5). Using software MACAW (Schuler $e t$ al., 1991), a block of homology (26.7\% identity and 53\% similarity) was found between the 60 C-terminal amino acids of the proteins specified by ORF 37 and gene 14 of B. subtilis phage $\phi 29$ (Steiner et al., 1993). These results suggest that the ORF 37 -encoded protein is a holin. The location of the bIL67 holin gene, $12.6 \mathrm{~kb}$ downstream of the lysin gene resembles the organization of $\mathrm{T} 7$, in which the holin gene (designated 17.5), is separated from the lysin gene (designated 3.5) by more than $25 \mathrm{~kb}$ (Dunn \& Studier, 1983), while most of the other holin genes map immediately upstream of the lysin gene.

\section{CONCLUSIONS}

bIL67 is the first prolate-headed phage from L. lactis for which the complete genomic sequence has been determined. Its genome is small and very compact since non-coding regions represent only $5 \%$ of the chromosome. It is organized in two transcriptional units, the early region and the late region, which represent $31 \%$ and $64 \%$ of the genome, respectively. Searches for protein homology allowed assignment of putative functions to products of three genes among the 37 identified. However, only one of these proteins shows homology with the product of a heterologous phage (erf gene of $S$. typhimurium phage $\mathrm{P} 22$ ). The three other assignments of function were based on analysis of protein structure or on the search for conserved domains. Phage proteins commonly show little or no amino acid homology with proteins from databases. Even the proteins which have the same function on different phages show little sequence conservation, and the similarities are mainly observed at the structural level, as illustrated by the case of the holin (Young, 1992) or the connector (Donate et al., 1993).

The presence of several different direct repeats (two discussed above and a third one flanking ORF 24) suggests that, like other phages (Campbell \& Botstein, 1983), lactococcal phages evolve by exchange of DNA modules. Moreover, these exchanges seem to involve essential functions such as DNA replication and recombination.

\section{ACKNOWLEDGEMENTS}

We thank Alexei Sorokin and Pascale Serror for introducing us to the large scale sequencing strategy, Vasco Azevedo for the $E$. coli strain JJC128F', Nathalie Galleron for technical advice, Christiane Nivet for the use of GeneMark software, Horst Neve and Paul Ritzenthaler for communication of unpublished results. We also thank Costa Anagnostopoulos and Alain Chopin for critical reading of the manuscript. This work was supported, in part, by EEC Grant BIO'T-C'T91-0263.

\section{REFERENCES}

Altschul, S. F., Gish, W., Miller, W., Myers, E. W. \& Lipman, D. J. (1990). Basic local alignment search tool. $J$ Mol Biol 215, 403-410. 
Anderson, S. (1981). Shotgun DNA sequencing using clonec DNase I-generated fragments. Nucleic Acids Res 9, 3015-3027.

Arendt, E. K., Daly, C., Fitzgerald, G. F. \& van de Guchte, M. (1994). Molecular characterization of lactococcal bacteriophage Tuc 2009, identification and analysis of genes encoding lysin, a putative holin and two structural proteins. Appl Environ Microbio! 60, 1875-1883

Belin, D., Hedgpeth, J., Selzer, G. B. \& Epstein, R. H. (1979) Temperature-sensitive mutation in the initiation codon of the $r$ IIB gene of bacteriophage T4. Proc Natl Acad Sci USA 76, 700-704.

Beresford, T. P. J., Ward, L. J. H. \& Jarvis, A. W. (1993). Temporally regulated transcriptional expression of the genomes of lactococcal bacteriophages c2 and sk1. Appl Environ Microbiol 59, 3708-3712.

Billard, P., Perrin, R. \& Branlant, C. (1992). Nucleotide sequence at the extremities of the linear genomic DNA of Lactococcus lactis bacteriophages. Poster presented at the CBL meeting in Nancy, France, 2-4 Sept 1992.

Black, L. W. (1988). DNA packaging in dsDNA bacteriophages. In The Bacteriophages, Vol. 2, pp. 321-373. Edited by R. Calendar. New York and London: Plenum Press.

Blanco, L., Bernad, A., Blasco, M. A. \& Salas, M. (1991). A general structure for DNA-dependent DNA polymerases. Gene 100, 27-38

Blanco, L., Bernad, A. \& Salas, M. (1992). Evidence favouring the hypothesis of a conserved $3^{\prime}-5^{\prime}$ exonuclease active site in DNA dependent DNA polymerases. Gene 112, 139-144.

Bläsi, U., Chang, C. Y., Zagotta, M. T., Nam, K. \& Young, R. (1990). The lethal $\lambda S$ gene encodes its own inhibitor. EMBO J 9, 981-989.

Borodovsky, M. \& Mclninch, J. (1993). Genmark: parallel gene recognition for both DNA strands. Comput \& Chem 17, 123-133.

Brenner, S. (1987). Phosphotransferase sequence homology. Nature 329, 21 .

Burland, V., Plunkett, G., Daniels, D. L. \& Blattner, F. R. (1993). DNA sequence and analysis of 136 kilobases of the Escherichia coli genome: organizational symmetry around the origin of replication. Genomics 16, 551-561.

Campbell, A. \& Botstein, D. (1983). Evolution of the lambdoid phages. In Lambda II, pp. 365-380. Edited by R. W. Hendrix, J. W. Roberts, F. W. Stahl \& R. A. Weisberg. Cold Spring Harbor, NY: Cold Spring Harbor Laboratory.

Chandry, P. S., Moore, S. C., Davidson, B. E. \& Hillier, A. J. (1994). Analysis of the cos region of the Lactococcus lactis bacteriophage sk1. Gene 138, 123-126.

Chopin, A., Chopin, M. C., Moillo-Batt, A. \& Langella, P. (1984). Two plasmid-determined restriction and modification systems in Streptococcus lactis. Plasmid 11, 260-263.

Chung, D. K., Kim, J. H. \& Batt, C. A. (1991). Cloning and nucleotide sequence of the major capsid protein from Lactococcus lactis ssp. cremoris bacteriophage F4-1. Gene 101, 121-125.

Devereux, J., Haeberli, P. \& Smithies, O. (1984). A comprehensive set of sequence analysis programs for the VAX. Nucleic Acids Res 12, 387--395

Donate, L. E., Valpuesta, J. M., Mier, C., Rojo, F. \& Carrascosa, J. L. (1993). Characterization of an RNA-binding domain in the bacteriophage $\phi 29$ connector. J Biol Chem 268, 20198-20204.

Dower, W. J., Miller, J. F. \& Ragsdale, C. W. (1988). High efficiency transformation of E. coli by high voltage electroporation. Nucleic Acids Res 16, 6127-6145.

Dunn, J. J. \& Studier, F. W. (1983). Complete nucleotide sequence of bacteriophage T7 DNA and the locations of T7 genetic elements. J Mol Biol 166, 477-535.

Gautier, M. \& Chopin, M. C. (1987). Plasmid-determined systems for restriction and modification activity and abortive infection in Streptococcus cremoris. Appl Environ Microbiol 53, 923-927.

Geis, A. (1992). Cloning and DNA sequence analysis of a lysin gene of the lactococcal bacteriophage P001. In Annual Report 1991, p. B94. Kiel, Germany: Federal Dairy Research Centre.

van de Guchte, M., Daly, C., Fitzgerald, G. F. \& Arendt, E. K. (1994). Identification of the putative repressor-encoding gene $\mathrm{cI}$ of the temperate lactococcal bacteriophage Tuc 2009. Gene 144, 93-95. Hill, C., Miller, L. A. \& Klaenhammer, T. R. (1990). Cloning, expression and sequence determination of a bacteriophage fragment encoding bacteriophage resistance in Lactococcus lactis. I Bacteriol 172, 6419-6426.

Hill, C., Miller, L. A. \& Klaenhammer, T. R. (1991). In vivo genetic exchange of a functional domain from a type II A methylase between lactococcal plasmid pTR2030 and a virulent bacteriophage. $J$ Bacteriol 173, 4363-4370.

Jarvis, A.W. \& Meyer, J. (1986). Electron microscopic heteroduplex study and restriction endonuclease cleavage analysis of the DNA genomes of three lactic streptococcal bacteriophages. Appl Environ Microbiol 51, 566-571.

Jarvis, A. W., Fitzgerald, G. F., Mata, M., Mercenier, A., Neve, H., Powell, I. B., Ronda, C., Saxelin, M. \& Teuber, M. (1991). Species and type phages of lactococcal bacteriophages. Intervirology 32, 2-9.

Kilpper-Bälz, R., Fisher, G. \& Schleifer, K. H. (1982). Nucleic acid hybridization of group $\mathrm{N}$ and group D streptococci. Curr Microbiol 7, 245-250.

Kim, J. H. \& Batt, C. A. (1991). Nucleotide sequence and deletion analysis of a gene coding for a structural protein of Lactococcus lactis bacteriophage F4-1. Food Microbiol 8, 27-36.

Kumar, A., Malloch, R. A., Fujita, N., Smillie, D. A., Ishihama, A. \& Hayward, R. S. (1993). The -35-recognition region of Escherichia coli $\sigma^{70}$ is inessential for initiation of transcription at an 'extended -10' promoter. J Mol Biol 232, 406-418.

Lakshmidevi, G., Davidson, B. E. \& Hillier, A. J. (1990). Molecular characterization of promoters of the Lactococcus lactis ssp. cremoris temperate bacteriophage $\mathrm{BK} 5-\mathrm{T}$ and identification of a phage gene implicated in the regulation of promoter activity. Appl Environ Microbiol 56, 934-942.

Letellier, L. \& Labedan, B. (1985). Release of respiratory in Escherichia coli after bacteriophage adsorption: process independent of DNA injection. J Bacteriol 161, 179-182.

Lillehaug, D. \& Birkeland, N.-K. (1993). Characterization of genetic elements required for site-specific integration of the temperate lactococcal bacteriophage $\phi \mathrm{LC} 3$ and construction of integrationnegative $\phi \mathrm{LC} 3$ mutants. J Bacteriol 175, 1745-1755.

Loof, M. \& Teuber, M. (1986). Heteroduplex analysis of the genomes of Streptococcus lactis 'subsp. diacetylactis' bacteriophages of the P008-type isolated from German cheese factories. Syst Appl Microbiol 8, 226-229.

Ludwig, W., Seewaldt, E., Klipper-Bälz, R., Schleiffer, K. H., Magrum, L., Woese, C. R., Fox, G. E. \& Stackebrandt, E. (1985). The phylogenetic position of Streptococcus and Enterococcus. $J$ Gen Microbiol 131, 543-551.

Miller, J. (1972). Experiments in Molecular Genetics. Cold Spring Harbor, NY: Cold Spring Harbor Laboratory.

Nakayama, S., Moncrief, N. D. \& Kretsinger, R. H. (1992). Evolution of EF-hand calcium-modulated proteins. II. Domains of several subfamilies have diverse evolutionary histories. $J$ Mol Evol 34, 416-448.

Ogasawara, N., Nakai, S. \& Yoshikawa, H. (1994). Systematic sequencing of the 180 kilobase region of the Bacillus subtilis chromosome containing the replication origin. DNA Res 1, 1-14. 
Paces, V., Vicek, C. \& Urbanek, P. (1986). Nucleotide sequence of the late region of Bacillus subtilis phage PZA, a close relative of phi29. Gene 44, 107-114.

Pearson, W. R. \& Lipman, D. J. (1988). Improved tools for biological sequence comparison. Proc Natl Acad Sci USA 85, 2444-2448.

Platteeuw, C. \& de Vos, W. M. (1992). Location, characterization and expression of lytic enzyme-encoding gene, lyt $A$, of Lactococcus lactis bacteriophage $\phi \mathrm{US} 3$. Gene 118, 115-120.

Poteete, A. R. (1982). Location and sequence of the erf gene of phage P22. L'irology 119, 422-429.

Poteete, A. R. \& Fenton, A. C. (1984). $\lambda$ Red-dependent growth and recombination of phage P22. Virology 134, 37-49.

Poteete, A. R., Fenton, A. C. \& Semerjian, A. V. (1991). Bacteria phage P22 accessory recombination function. Virology 182, 316-323.

Potter, N. N. (1970). Host-induced changes in lactic streptococcal bacteriophages. J Dairy Sci 53, 1358-1362.

Sambrook, J., Fritsch, E. F. \& Maniatis, T. (1989). Molecular Cloning: A Laboratory Manual. Cold Spring Harbor, NY: Cold Spring Harbor Laboratory.

Schouler, C., Bouet, C., Ritzenthaler, P., Drouet, X. \& Mata, M. (1992). Characterization of Lactococcus lactis phage antigens. Appl Environ Microbiol 58, 2479-2484.

Schuler, G. D., Altschul, S. F. \& Lipman, D. J. (1991). A workbench for multiple alignment construction and analysis. Proteins Struct Funct Genet 9, 180-190.

Shearman, C., Underwood, H., Jury, K. \& Gasson, M. (1989). Cloning and DNA sequence analysis of a Lactococcus bacteriophage lysin gene. Mol \& Gen Genet 218, 214-221.

Smith, G. R. (1983). General recombination. In Lambda $I I$, pp. 175-209. Edited by R. W. Hendrix, J. W. Roberts, F. W. Stahl \& R. A. Weisberg. Cold Spring Harbor, NY: Cold Spring Harbor Laboratory.

Sorokin, A., Zumstein, E., Azevedo, V., Ehrlich, S. D. \& Serror, P. (1993). The organization of the Bacillus subtilis 168 chromosome region between the spoV $A$ and ser $A$ genetic loci, based on sequence data. Mol Microbiol 10, 385-395.

Staden, R. (1982). Automation of the computer handling of gel reading data produced by the shotgun method of DNA sequencing. Nucleic Acids Res 10, 4731-4751.

Steiner, M., Lubitz, W. \& Bläsi, U. (1993). The missing link in phage lysis of Gram-positive bacteria : gene 14 of Bacillus subtilis phage $\phi 29$ encodes the functional homolog of lambda $\mathrm{S}$ protein. $J$ Bacteriol 175, 1038-1042.

Terzaghi, B. E. \& Sandine, W. E. (1975). Improved medium for lactic streptococci and their bacteriophages. Appl Environ Microbiol 29, 807-813.

Vlcek, C. \& Paces, V. (1989). Nucleotide sequence of the late region of Bacillus subtilis phage phi-29 completes the 19285 bp sequence of phi-29 genome: comparison with the homologous sequence of phage PZA. Gene 46, 215-225.

de Vos, W. M. (1987). Gene cloning and expression in lactic streptococci. FEMS Microbiol Rev 46, 281-295.

Walker, J. E., Saraste, M., Runswick, M. J. \& Gay, N. J. (1982). Distantly related sequences in the $\alpha$ - and $\beta$-subunits of ATP synthase, myosin, kinases and other ATP-requiring enzymes and a common nucleotide binding fold. EMBO $J$ 1, 945-951.

Ward, L. J. H., Beresford, T. P. J., Lubbers, M. W., Jarvis, B. D. W. \& Jarvis, A. W. (1993). Sequence analysis of the lysin gene region of the prolate lactococcal bacteriophage c2. Can J Microbiol 39, 767-774.

Watanabe, K. \& Takesue, S. (1972). The requirement for calcium in infection with Lactobacillus phage. J Gen Virol 17, 19-30.

Weaver, S. \& Levine, M. (1977). Recombination circularization of Salmonella phage P22 DNA. Virology 76, 29-38.

Yanisch-Perron, C., Vieira, J. \& Messing, J. (1985). Improved M13 phage cloning vectors and host strains : nucleotide sequences of the M13mp18 and pUC19 vectors. Gene 33, 103-119.

Young, R. (1992). Bacteriophage lysis : mechanism and regulation. Microbial Rev 56, 430-481.

Zimmermann, J., Voss, H., Kristensen, T., Schwager, C., Stegemann, J., Erfle, H. \& Ansorge, W. (1989). Automated preparation and-purification of M13 templates for DNA sequencing. Methods Mol Cell Biol 1, 29-34.

Received 20 June 1994; revised 14 July 1994; accepted 20 July 1994 